University of Louisville

ThinkIR: The University of Louisville's Institutional Repository

Electronic Theses and Dissertations

$5-1921$

\title{
History of the churches of Louisville with special reference to slavery.
}

Homer E. Wickenden

University of Louisville

Follow this and additional works at: https://ir.library.louisville.edu/etd

\section{Recommended Citation}

Wickenden, Homer E., "History of the churches of Louisville with special reference to slavery." (1921). Electronic Theses and Dissertations. Paper 1564.

https://doi.org/10.18297/etd/1564

This Master's Thesis is brought to you for free and open access by ThinkIR: The University of Louisville's Institutional Repository. It has been accepted for inclusion in Electronic Theses and Dissertations by an authorized administrator of ThinkIR: The University of Louisville's Institutional Repository. This title appears here courtesy of the author, who has retained all other copyrights. For more information, please contact thinkir@louisville.edu. 


$$
\text { UNIVERSITY OF LOUISVILLE }
$$

\title{
HISTORY OF THE CHURCHES OF LOUISVILLE \\ WITH SPECIAL REFERENCE TO SLAVERY
}

\section{A DISSERTATION}

SUBMITTED TO THE FACULTY OF'THE GRADUATE SCHOOL OF ARTS AND SCIENCE IN PARTIAL FULFILMENT OF THE REQUIREMENTS FOR THE DEGREE OF MASTER OF ARTS

\author{
Department of Applied Soclology \\ by \\ Homer E. Wiokenden \\ 1921.
}


In the one hundred and forty years of Louisville's existence, it has grown from a log cabin settlement with no churches to a city with 269 churches and church property valued at over $\$ 30,000,000$.

It is impossible to measure the moral and religious force that they have exerted on the city. It can best be appreciated when one thinks of what the city would be without them. Few of us would care to live in such a city.

In the field of education, Louisville

churches have contributed much. Some of the first sehools in the city were conducted by ministers, and the work done by the various Catholic orders in this field have been far reaching. Louisville churches have contributed numerous college presidents. One of the first night schools in the city was started by a group of church men. Louisville children have had Sunday Schools to attend for the past ninety years. The location in Louisville of Baptist, Presbytorian, and catholic Theological Seminaries and the Baptist Missionary Training School has meant much to the various churches of the city.

Most of Louisville's charitable organizations, hospitals, and orphanages were started by churches and church people. During both the Civil War and the recent World War much work was done, not only in the care of the sick and the wounded, but in providing inspiration, recreation, and hospitality for the soldiers quartered in the city. 
But the greatest moral question that ever faced the churches of Louisville was that of slavery. The positions the local churches took on this issue can scarcely be separated from those of their national and state organizations, especially in the methodist, Presbyterian, and Baptist Churches.

Without doubt the attitude of many masters to their slaves was affected by the decisions of the church. As McDougle in his volume on Slavery in Kentucky (P.93) says," Slavery in Kentucky was a comparatively mild form of servitude. -.- There were various elements that devised schemes for exterminating the institution. This was especially true of the churches which represented more than any other one force the sentiment of the state on the subject of emancipation."

There are several histories of the various churches of Louisville, but none of them develop the discussion of the slawery problem very far. In this paper the object has been to give the history of the church growth in Louisville more or less in outline form, and at the same time, to bring out especially the relation of the churches to slavery.

The effect of slavery and the Civil War on the church was probably stronger than the effect of the church on them. The bitterness and hatred created by slavery and the war tore the churches asunder and in this separation the Louisville churches played a strong part. Interesting legal questions regarding church government and authority were developed, especially, the relations 
of Church and State in the separation of the Methodist and Presbyterian Churches. These disputes illustrate the tendency of moral and religious principles to be influenced if not determined by economic expediency.

H.E.W., Louisville. Nay, 1921.

\section{THE BEGINNINGS.}

In the settiement of. Kentucky there were few events of importance in the religious field previous to 1800. The Baptists, Episcopalians, and Presbyterians were among the earliest settlers. Smith's History of Kentucly says, "After the close of the Revolution a flood of Baptists poured into Kentucky. ' In 1776, William Hickman began to preach at Harrodsburg. He later visited Louisville." However, Johnston's History of Louisville says that the first ministers in Kentucky were Presbyterians. They organized many churches and schools. Father Badin, a French Priest, was known to have been in Louisville in 1794.

The irregular life of the pioneers did not lend itself to religious organization, for holding meetings was difficult, and preachers were very saarce. Further, the presence of adventurers who had left the older states in the East for the good of the community did not strengthen the moral and religious sentiment of the country. The religious life as a whole was languid and made an inviting field for evangelistic effort. $* 2$ 
Kentucky is famous for its religious revival of 1800, which took place in Logan County. Here some 20,00 people gathered camping out and holding numerous outdoor services. Great excitement resulted from the assemblying of the crowd, and it was not long before the people, even the most sober ones, became subject to fits of hysteria, characterized as the jerks and falling exercises. Some victims of this nervous disorder were in a Semi-unconscious state for nine days. *3

But the results were not very lasting. The after affects of the War of 1812 were demoralizing in the extreme, and the state of religion in Kentucky was very low at its close in January, 1815. Deism and infidelity resumed their sway which had been broken by the revival of 1800. The reports of all the ecclesiastical bodies in this period are low in tone. $* 4$

There is no indication that this revival had any strong affect in Louisville, for the first church was built about 1803, and the second church, a Catholic church, in 1811. Some claim that the first sermon preached in Louisville was by a Baptist, squire Boone, brother of Daniel Boone, but others concede this honor to an, Episcopalian clergyman. Durett ${ }^{* 5}$ says, "There was a pioneer. church in Louisville near the old 12th St. Fort which was used by all denominations in early times. It stood on the northwest corner of Main St. and I2th. It was a simple *3 - Davidson - Presbyterian Churches in Kentucky. Chap V. *4 - Dosker - Souvenier Program General Assembly, 1912. *5 - Durett - Centenary of Louisville. P.161. 
structure made of unhewed logs. It was 30 feet 1 ong and 20 feet wide. It is possible that Mr. Kavanaugh in 1803 got possession of this old church and after putting it in order officiated in it while he was in Louisville: There is no known account printed or written of any other church at this early date, and tradition has handed down nothing relating to another. Nearly twenty years passed before there was any organized church at the Falls of the Ohio."

- The development of religion in Louisville can best be traced through the history of the various denominations.

\section{Episcopal.}

On May 28, 1775, Rev. John Lytle (or Lisle), a clergyman of the Church of England, held one of the first religious services in Kentucky. Christ Church in Lexington was the first Episcopal Church in Kentucky. It was organized in 1794. Rev. Wm. Kavanaugh, who was converted from the Nethodist forth, was ordained in the Episcopal Church in 1800, and he was conducting services in Louisville in 1803. He moved to Henderson a few years later. No effort to organize an Episcopal Church was made, however, until about 1820. There is preserved in the archives of the Diocese of Maryland a manuscript letter from Rev. Joseph Jackson to Bishop Kemp of Maryland, da.ted Bardstown, Ky., Sept. 28, 1820. We do not know under What auspices Mr. Jackson had come to Kentucky but evidently he writes to his own bishop to give him a report of his doings and of the condition of ecclesiastical affairs 
which he found. His hope had been, but we do not know for how long, "That a subscription would be made up in Louisville for an Episcopal Clergyman, but so much caprice and indifference to everything religious prevalls that delay has been added to dolay. -.. The excessive heat and prevailing disease in Louisville has prevented me from tarrying but an hour or two at a time in town." He left a subscription paper in the hands of two or three gentlemen who have promised to attend to it. He feared that the time had passed when the Episcopal Church could have been established with immediate strength, but he added, "There are still nominal adherents in a sufficient number to induce, I think, a completent provision in several places, and the general insufficiency of the other ministrations, the evident lukewamness that prevails with little or no exception, where I have been, and the known fruits of the Episcopal ministrations in some places these considerations induce with the thinking and serious, even of different denominations a wish for Episcopal Clergymen.

He concludes his letter of October 5th "The subscription in Louisville has not progressed much during my absence, but I think there is still hope from the character of some of the subscriptions.' -.-.- My wish is for a minister of the very finest grade to officiate in Louisville; none other would answer. His eloquence, especially, must be winning, commanding, and irresistable. But, he added, without a Bishop I see no prospect of a permanent Episcopalian establishment in 
the State." $* 6$

The Diocese of Kentucky was organized in 1829 with three resident clergymen and three parishes. In 1831 the first official report shows sixty-one communicants in Louisville, ninety-two in Lexington, . and twenty-seven in Danvilie. The first Bishop was elected in 1832

The first meeting of Episcopalians to erect a church in Louisville was held in Washington Hall on Friday, May 31, 1822. The committee appointed to manage the building of the church consisted of : Messrs. Peter B. Ormsby, Dennis Fitzhugh; Samuel Churchill, James Hughes, Wm. I. Thompson, Richard Barnes, and Wm. H. Atkinson. The church was started in 1823. It was a rame house on the present court House lot on 5 th near the corner of Jefferson.

At this time the population of Louisville was 1886 whites and 1126 negroes, total 3012 . On March 11, 1824, at a meeting of the congregation of Christ Church, Rev. Henry Shaw was elected rector at a salary of $\$ 1200$ commonwealth money, equal to \$600 in Specie.

Christ Church on 2nd St. between Liberty and Walnut, the church st11l in use, was built in 1824-5 under Rev. D.C. Page, rector. *7 Among the rectors of importance was James Craik who came to Louisville in 1844. He served until 
June, 1882. He was a very man of very strong character. He was opposed to secession when it was not popular to be so. He was president of the General Convention for fifteen years, and to him is due the credit of preserving peace in the church during the war. In 1881 his son, Rev. Chas. E. Craik, was made his assistant. Rev. Chas. E. Craik, Jr., is pastor of St. Thomas Church at the present time. $* 8$

On September 28, 1834, twelve people met at the Louisville Hotel to organize St. Paul's. The cornerstone was laid for their church on April 29, 1837, but because of the panic they were unable to continue building. The congregation met in Mechanics Hall on 6 th St. near Walnut until 1839, when, with the help of Christ Church, the building was finished. January 25th, 1894, the church burned, and the present church at 4th Ave. and St. James Ct. was erected. It was dedicated on Easter, April 5, 1896. St. John's Church was built in 1847 with the help of St. Paul's and Christ Church. It had a struggle during its whole existence. In 1890 the minister; Rev. Stephen Elliott Barnwell, was receiving only $\$ 600$ a year. On March 27, 1890, the church was destroyed by cyclone, and he and his baby boy were killed. He was later succeeded by a cousin and then his brother. This church was disbanded in 1916.

Grace Church on Gray St. near Preston was *8- In Memoriam James Craik. P. 16. 
organized in 1855 as a mission of Christ Church. St. Andrews was organized in 1865. In 1865 it built at corner of 2 nd and Kentucky.

St. Peter's in Portland was organized in 1850 but was not admitted to the church union until 1868 . It has always had a feeble life.

In 1860, the congregation of Methodists, worshipping in Sehon Chapel, corner of 3rd \& Gutherie, resolved, under the leadership of the minister, to enter the Episcopal Church if they should be helped to pay the debt resting upon their church. This help was given by Christ Church and St. Pail's, and the transfer of the minister was made. The minister, however, did not stay long. This was the beginning of Calvary Church. Rev: Geo. Everhart was the rector at the time the church was admitted to the Convention. Under Rev.W.M.Platt the church was sold back to the Methodists and a building started on 4 th St. near York. $* 9$

The Church of the Advent began as a mission of Christ Church on Broadway. About 1880 the present church on Baxter \& Cherokee Road was organized. It was at this church in 1920 that a Mr.Hickson, a layman from England, attempted to revive an interest in spiritual and physical healing by the laying on of hands.

St. Mark's African Church was organized in 1867 under Rev. Atwell but died out shortly. Later the Church of Our Merciful Savior was built on Madison near loth *9-Craik's Historical Sketches of Christ Church. P. 125. 
and more recently the present church at IIth \& Walnut was built.

At the present time Louisville has fourteen Episcopal Churches, one of which is colored.

In 1835 the Protestant Episcopal Female Orphan Asylum was opened in a house on the north side of Narket St. between 9 th \& 10th. Six children entered at the opening. Later the house was located at 5th \& Chestnut and now is on College St. near Floyd.

Under the patronage of the Episcopal Church an Orphanage was started for boys in October, 1870, by Miss Sarah Clayland. It was named the Orphanage of the Good Shepherd and under the supervision of the Sisters of Martha.

The Home of the Innocents was started on Washington St. by Rev. Dr. Helm, chiefly as a Day Nursery, where poor women might leave their children when working. The present home was a gift from five men.

In 1882 the church home and infirmary on Norton Ave. This same year a society of girls in St. Paul's Church who agreed to work for a fund to erect a protestant hospital started the John H. Norton Memorial. Infirmary.

Catholic.

The Diocese of Kentucky was established in April, 1808. Rev. Benedict Flaget, D.D., was consecrated bishop of Bardstown in 1810. The Diocese of Louisville now includes that part of Kentucky west of Carroll, Owen, 
Franklin, Woodford, Jessamine, Garrard, Rock Castle, Laural, and Whitley Counties. $* 10$

The first Catholic Church to be built in Louisville was erected in 1811 by Rev. Father Badin on Main St. near the head of the canal. The City Directory of 1832 says that the chapel was not in use at that time "but will be fitted up when the increase in that part of the city requires it.

The directory contains the following regarding the next Catholic Church in the city, "The Catholic Chapel of St. Iouis situated on 5th St. near Walnut, erected at considerable expense is yet unfinished. The bullding is ninety five feet and including the recess for the alter 115 feet long, 54 feet wide - has school rooms in the basement story. There are to be buttresses extended along the sides of the church, and the whole surrounded by minarets. The Rev. R.A.Able is pastor. The building in the rear of the lot upon which the church is built is occupied by the ladies of the order denominated "Sisters of Charity", a society so justly celebrated at Emmetsburg in Maryland, Nazareth in this State, and many other places in the union for their success in the education of young ladies. This school consists of from fifty to sixty scholars at present and is rapidly increasing. When their means will be sufficient, they will receive, clothe, educate, and support a number of orphan children, towhich purpose the profits of this admirable institution are *10- The Official Catholic Directory 1921. 
devoted."

This St. Louis Chapel was used until 1841. It was in this year that Bishop Flaget found that Bardstown was not gaining in importance, and he had the lee transferred to Louisville. *Il This gave the Catholic religion a new impetus in Louisvilie.

The present Cathedral of St. Mary's of the Assumption was begun in 1849. It was three years in building and cost $\$ 80,000$. It contains some of the paintings which were brought from Bardstown. The first priest at the Cathedral was Father Benjamin Spalding. He gave $\$ 10,000$ out of his own paternal inheritance to help in the erection of the Cathedral. He later became Bishop. Bishop Flaget ras buried in the Cathedral in February, 1850.

The church of st. Boniface was begun in 1836 by Father Stahlschmidt, principaliy for German people. It was located on Fehr Ave. near Jackson.

In 1841 the cornerstone was laid of the church of Our Lady in Portland *12 originally known as Notre Dame. du Port. The early members of this congregation were chiefly natives of France. Father Badin gave the land on which it was built. Father Napoleon Perche was the first priest. Another building was built by this congregation in 1867, considerably larger in size. As this had a so-called "self-supporting roof" which spread the walls it had to be rebuilt in 1870 .

The old St. Patrich's church was built in 
1853. But the present church, corner 14th \& Market was built in 1863. St. Martins was built on Shelby St. in 1853. Father Leander was the priest. A $\$ 10,000$ organ built in Munich was installed in this church. St. John's church was organized in 1854 and the next year the building at clay \& Vialnut was put up. In 1855 St. Peter's Church was organized in the section out 18th St. known as California. The present church was built by Father Beyhurst in 1866. St. Anthony's 23rd \& Market was organized In 1866. A church was built in 1867 and the present large church erected in 1884. St. Michaels Church on Brook St. between Harket \& Jefferson was purchased from the Hethodists in 1866. St. Louis Bertrand on 6 th St. was first built in 1866. The present church was erected in 1869 and dedicated in 1873. It has a large school under the Dominican Sisters from the Mother House of St. Catherine near Springfield, Ky. St. Augustine's Church for colored was built in 1869 , at 14th \& Broadway. It has a white priest. Sacred Heart Church was first built in 1872., but a larger one was soon needed. In 1885 a new church was built. It was destroyed by the tornado in 1890 and rebuilt in 1892. In 1873 St. Briget's was organized at corner of Baxter \& Payne Sts., but in 1890 moved to Baxter \& Hepburn. St. Cecelia's was built in 1873 on a lot donated by Thomas Slevin and the work of erection put in the hands of the carmelite Faters whom the Bishop had invited to labor in the mission of the Diocese. 
Other churches and their dates of organization are: St. Vincent de Paul, 1877, St. Joseph's on Washington St., 1866, St. Charles Barromeo on Chestnut, in 1888, St. Mary Magdelen's on Brook St. in 1892, St. Francis, Bardstown Rd., 1886, St. Paul's on Jackson St., 1888, The Holy Name Church, 4th \& 0. Sts., 1891, St. Aloysius, Payne near Baxter in 1891, and Holy Cross, 32rd \& Broadway, 1895. The most recent church is St. Benedict's which was organized April 8th, 1921. Plans are under way for a church at 25 th \& Osage Streets.

\section{The Sacred Heart Retreat on the Newburg} Road is the home of the Passionist Fathers. It was purchased in 1875. St. Agnes Church is now in connection with it. The chief function of the passionists is to give retreats to religious communities and missions to the various parishes.

St. Vincent's Orphan Asylum was founded In 1832 when the cholera epidemic broke out in Kentucky. Mother Catherine took two little girls. Fifteen others were soon admitted. Later in 1836 the asylum moved on Jefferson St. where it remained until 1891 when it was removed to Newburg Rd. St. Joseph's Infirmary grew out of the asylum on Jefferson St. in 1837.

The House of the Good Shepherd was started in December, 1842, by five sisters who came from France. Their home at 8th \& Madison was the first "Magdelen Home" under such auspices in the United States. *13 
The Little Sisters of the poor came to

Louisville in 1869. Sts. Mary and Elizabeth's hospital was opened in 1872 .

The value of the services of these sisters. before we had trained nurses is well illustrated by the fact that during the smallpox epidemic of 1873 with the Bishop's permission, Dr. Ford went to Nazareth, Ky., in the name of the Mayor and Board of Health to request the Sisters to take charge of the new hospital pr pest house. Sister Euphemia of St. Joseph's Inflrmary was placed in charge. As a result the attitude of the people toward the pest house was changed. They did not look on it as certain death, but all classes of people were willing to go. The sisters stayed in charge until the following summer. In 1892. they took charge of St. John's Emptive Hospital which later the city took over. $* 14$

There are now thirty-nine Catholic churches in Louisville and five religious orders for men, nine for women. Rev. Denis O'Donaghue, D.D. is Bishop. He was consecrated in 1874 and came to Louisville in 1910.

\section{Baptist.}

The first Baptist church in Jefferson County was located a little south of what is known as Eight Mile on the Shelbyville Pike in January, 1784. This was known as the Baptist Church of Beargrass. In 1803 the Long Run Baptist Association was organized to take in the churches *14- Johnston- Memorial History. Vol 2. P. 120 
of Shelby, Spencer, Bullitt, Jefferson, and part of Hardin Counties. This assoclation was merely a gathering for consultation and advice.

In 1815 in the house of Mark Lampton a little east of the Marine Hospital the Rev. Hinson Hobbs organized the lst Baptist Church of Louisville with fourteen members, both colored and white and in 1842.559 colored members were organized into a church, leaving only 279 white members. The church was located at the southwest corner of 5 th and Green St. It was from this church that all of the members but 85 separated to join the Reformed Baptist Church, now the Christian Church.

In 1842 also the East Baptist Church was organized with seven members.

In 1838, nineteen members of the lst church organized the 2nd Baptist Church. They leased a lot on Green St; between Ist and 2nd Sts, and erected a church costing $\$ 3000$. In 1849 the lst and 2nd Churchs became pastorless. They both called Rev. Thomas Smith, Jr., who accepted both calls and brought the two churches together, forming the Walnut st. Church, which has been one of the most powerful churches of the Baptists of the South ever since. They purchased a lot at the comer of 4 th \& Walnut on which they built a fine Gothic Church, although they had very little money to start it.

Wm.W.Everts was called to succeed Thomas Smith in charge of the Walnut St. Church about 1853. He remained seven years. He was a man of great energy and enterprize 
but he came to Louisville just at the time when the excitement on the slavery question was at fever heat. He was opposed to slavery and was perhaps independent in manifesting his oppositions. Prejudice was soon excited against him and the Baptists divided into two parties under Dr. Everts and Dr. Ford who was one of the editors of the Christian Repository. The excitement soon extended far beyond the city limits and party spirit grew extremely bitter. Nembers excluded from one church were immediately received into the of another. In the city the Evert party was in the majority, but in the country the Ford party. Dr. Everts went to Chicago in 1859.

Dr. Ford left in the Fall of 1861 and went south. He was a member from Kentucky of the first confederate States Congress.

Rev. George Lorimer who had been an actor and who was converted during some special meetings became pastor in December, 1861. He was very successful during the war, and the church grew so that it was decided to colonize and build the Broadway Church. It is interesting that many of the largest subscriptions to the new church were from those who did not expect to leave the old church.

In May 1881, Dr.T.T.Eaton became pastor. At one time during his pastorate, 711 members were granted letters to form the church at 22nd \& Walnut St. Yet despite these and other losses the number of members increased during his pastorate from 750 to 1650 . The entire number of additions from 1881 to 1896 was 3600 , and the 
money raised for benetolent objects during the same time was $\$ 500,000$. This church is the mother church of the denomination in the South. The present church, corner of St. Catherine \& Third, was dedicated November 16, 1902. The first colony sent out by the Walnut St. Church was the German Baptist Church in 1853 at the corner of Broadway and Hancock. *16

A resolution presented to the Long Run Association says:

Whereas, the German Baptist Church in the city of Louisville is surrounded by a German population of some 18,000 souls very destitute of Gospel preaching,and whereas sald church has a valuable house and lot on which they owe only $\$ 700$.

Resolved that we recommend the friends of Christ in our midst to assist this infant and growing church in raising the means to relieve it from debt.

In 1854 the Chestnut St. Church was organized and the Portland Ave. Church colonized, the lots for both churches being paid for by the Walnut St. Church. In 1869 a church was started on Cabel St. which later became the Franklin St. Church. The East Baptist Church now on Chestnut near Preston was organized in 1842 .

In 1870 the Broadway Church was organized by 110 members of the Walnut s.t. Church. The building was built before the church was organized. This has always been a strong church and more than once has led all the churches of the Southern Baptist Convention in contributions to 
foreign missions, and members of this church, chiefly the Nortion family, have contributed more than $\frac{3}{4}$ million doliars to the seminary. $* 17$

In 1887 the 22nd \& Walnut St. Church was built at a cost of $\$ 25,000$.

In 1890 the McFerran Memorial Church, now the 4th Ave. Baptist Church; was organized. In $1883 \mathrm{Mr}$. and Mrs. John B. McFerran gave the lot to the Walnut St. Church. After the death of their son in 1886 they gave $\$ 25,000$, provided the Walnut st. Church would add $\$$;10,00 for the erection of a lecture room.

In 1895 two hundred of the members of the Walnut st. Church started the 3rd Ave. Church.

The Baptist Tabernacle at 26th \& Marke $t$ was organized by the 22nd \& Walnut Church and in 1896 had 900 members.

The Highland Church was organized in 1893; the Logan St. Church in 1895; and the Parkland Church in 1887 .

The city directoryfor 1832 shows that the Baptist Church devoted to colored persons is situated on Market St. between 7th \& 8th. Also the African Church on Centre St. near Green.

The minutes of the Long Run Association for September, 1839, read as follows:

"The First Baptist Church has in its connection and under its care a large African Church consisting of about 300 members. They are in a large new brick building put up by their own means. Elder Henry *17-Johnston Memol History Vol 2. P. 196. 
Adams, a talented colored brother, is their pastor and preaches to them every Lord's Day and receives for his support $\$ 500$ a year. In 1843 this church numbered $745^{4}$ The letter in the minutes of 1845 shows resentment toward the Foreign Mission Board which had been influenced by abolitionism in sorth

In 1842 the 5th Ave. Church was organized with a membership of 559. This church has had as high as 1600 members. Dr. John H. Frank, pastor - physician, has been in charge for over 25 years.

In 1896 there were elghteen other colored Baptist churches and over 5000 members. These churches belonged to the Iong Run Association along with -the Winite churches, but in 1871 they withdrew and formed thelp own General Association.

There are now thirty-two white and forty colored Baptist churches in the city.

In 1866-67 - perhaps due to the war -

a number of orphans were in the care of the Walnut St. Church, and as a result the Baptist Orphans' Home was started. In 1869 Mrs. J. Lawrence Smith gave a lot $200 \mathrm{ft}$. square at Ist \& St. Catherine and $\$ 5000$ for the home.

There is Iittle to indicate that the Baptist Churches in Louisville ever took a decided stand on the subject of slavery. The Long Run Association minutes for 1807 show that the question of the right of a slave to join the church was presented, this privilege being granted when the master consented. A letter in the minutes of the 
1845 Association meeting show some resentment toward the Baptist Board of Foreign Mission which had been influenced by abolitionism. Even the Vester Recorder, the Baptist Weekly published in Louisville, just preceding the outbreak and during the Givil War, printed very little regarding slavery or secession, its pages being given over largely to doctrinal disputes.

The Baptists of Louisville, although now very powerful in the Southern Baptist Convention, had practically no part in its organization, which occurred in 1845 at Augusta, Georgia. The convention was a protest against the action of the "Acting Board" in refusing to consent to the appointment of a slave-holder to any field of foreign missionary labors. *18

The Charleston Mercury commented on its action thus "When we are forced out of the church by the Northern fanaties we shall next be forced out of the Union by the same nefarious arts." - indicating the connection between religious and political feeling. *19

"In June of the same year year the Kentucky Baptists for the most part withdrew from the northern organization and pledged themselves to this newly formed convention. The creed was not changed. It was simply a matter of rebuke toward the northern sections attitude on the slavery question".

Dr.E.Y.Mullins, president of the Southern Baptist Theological Seminary, was elected president of the 
Southern Baptist Convention in May, 1921.

\section{Presbyterian.}

As early as 1789 a number of Presbyterian families located near kiddletown and built a church. They called as poastor, a Rev. James Vance who accepted in 1799. The appointment by the Presbytery of Transylvania dated 1800 read that he was to "preach to the congregation at Louisville." *20 In 1816 a Presbyterian Society was formed by the citizens, and Rev. Daniel C. Banks, a congregational minister from Eairfield, Connecticut, who came to Kentucky as a missionary, was chosen pastor. He was to have a salary of $\$ 900$ for half time. He opened a school along with his wife's sister, Miss Mary Ann Silliman. In 1817 a confession and covenant were adopted, and a house of worship was erected on the west side of 4 th St. $104 \mathrm{ft}$. south of Market St.

In $1818 \mathrm{Mr}$. Banks officiated at the funeral of George Rogers Clark.

We learn from the minutes of the First Church that in accordance with a custom of the times, the names of those who were present at the Lord's Supper were recorded and also those absent. Persons visiting the city and who wished to commune were required to obtain permission beforehand from the session of the church. $* 21$.

For the period of $1822-23$ when the town was almost depopulated by a malignant fever, the records of the 
church contain several mourning pages which mention the names of members of the church who had been carried off.

Two years later under Rev. Gideon Blackburn D.D. a revival swept over the city and in three years the membership increased from fifty to 130. The congregation became one of the wealthiest and most influential in the state. Dr. Blackburn was called to the presidency of Centre College in October, 1827. In 1829 Rev. Fli Sawtell, an evangelist from New England, took charge.

The 2nd Presbyterian Church was organized April 17, 1830, under Rev. Sawtell who left the lst church. The building on 3rd St. 297 feet south of Green was dedicated in 1832. He reported "Instead of the school house in which we began to worship, the Lord enabled us within three years to build a commodius brick church with a regular congregation of from seven the eight hundred, and increasing the church membership from 12 to 160 with week day schools for little children, and Sunday Schools so prosperous and vigorous as to attract the attention of passing strangers. Rev. Edward P. Humphrey, son of Rev. Herman Humphrey, the President of Amherst College, was called as pastor from Jeffersonville in 1832 .

In May 1832, plans were put under.way for organizing the Third Presbyterian Church in the eastern part of the city, but they'were abandoned in 1834.

In 1832 also a church popalarly known as the Fourth Presbyterian Church was started on Chapel St. between Main and Market. Services were heid in a rame 
dwelling on the south side of Market St. below loth st. In 1835 a church was built on the east side of loth St. between Viarket and Jefferson Sts. This congregation was re-organized in April, 1836, as the Third Presbyterian Church. In 1854 this congregation moved to the northeast corner of Walnut and llth St. This was the church involved in the extended litigation of 1866 to 1871.

The Fourth Presbyterian Church was organized March 8, 1846, and services were held in Hayes' and Coopers' Wagon Shop at Main \& Hancock Sts. On August 22, 1847, Rev.. Nason D. Williams was called as pastor.

The Chestnut st. Church was organized October 31, 1847, with sixty-five members. A lot 105 ft. by $180 \mathrm{ft}$. on the south west corner of $4 \mathrm{th} \&$ Chestriut was purchased at a cost of $\$ 6275$. A lecture room on Fourth Cross Street (Broadway) between Chestnut \& Prather was dedicated on December 26, 1847. Broadway was then the southern limit of the city, there being at that time but few houses beyond chestnu t St. The church building at 4 th. \& Chestnut was completed in February 1850. The main building was brick, in Grecian style with a portico projecting supported by six large columns. A lady member of the church writing to her husband in the East says, "An organ has been placed in the church. They say it will not be used during services but is intended only for choir practice."

The Portland Ave. church was organized in September, 1855. 
In 1866 before the Louisville Presbyterian Church split, there were six churches with a total membership of 1279, as follows:

$\begin{array}{lr}\text { Ist Church } & 285 \\ \text { 2nd Church } & 356 \\ \text { 3rd or Walnut St. } & \\ & 111 \\ \text { 4th Church Church } & 140 \\ \text { Chestnut St. Church } & 334 \\ \text { Portland Church } & 83\end{array}$

It is interesting to note that the Presbyterian Church in Louisville previous to 1866 sent to the Presidency of Centre College Dr. Gideon Blackburn; to the Presidency of oakland College, Mississippi, Rev. W.L. Breckenridge D.D.; to the Pheological Seminary, Danville, Ky.the Ref. E.P. Humphrey D.D.; to the Presidency of Austin, Texas, College, Rev. A.E. Thorn; to the presidency of Hanover College, Indiana, Rev. Sylvester Scovel; to the Presidency of wooster College, Ohio, Rev.A.A.E.Taylor; to the Presidency, of Sayre Female Institute of Lexington, Prof.S.R. Williams; and to the Theological Seminary of the Northwest in Chicago, Rev. J.L.Halsey. ${ }^{* 23}$

In 1838 the Presbyterian General Assembly was split into what was known as the New and Old Schools. The controversy was concerned chlefly with questions of theology and doctrines. $* 24$ While there were representatives of both schools in Louisville, no great difficulty arose the majority staying with the old school. 25 These two factions united in $1869 . * 26$.

*23- Johnston - Memorial History. Vol. 2 P. 167. *25- Johnston - Memorial History.Vol. 2 P. 167. *24- Davidson, Presbyterian Church in Kentucky P. 342 *26- Courier Journal November 13, 1869. 


\section{Slavery in Kentucky.}

For a satisfactory understanding of the history of the churches of Louisville, especially the Presbyterian and Methodist Churches, some statements as to slavery and the attitude of the various churches on it is necessary.

In 1850 there were 761,413 whites in Kentucky and 210,981 slaves. $* 27$. In Jefferson County in 1860 there were 77,093 free whites, 10,304 slaves, and 2007 free negroes. $* 28$

That slave holders were deeply interested in the welfare of their slaves is illustrated by the position of one elder discussing emancipation in the Kentucky Synod of the Presbyterian Church. *29 In asking the advice of the Synod; he stated emphatically that he had no desire to hold them in bondage, but that he was willing to do whatever was best for the slaves themselves. If he should free them what would become of the aged and the women and the children. Furthermore, it was a serious matter to give bond and security for the support of so many slaves of different ages and character. He could not send them out of the state, for they were intermarried with slaves of others; and as to giving them wages, he could not for they were eating him up as it was.

The labor value of an agricultural slave in the State steadily decreased after about 1830. There was a certain amount of profit in the labor of able bodied slaves, but they represented only a fraction of the 
negroes whom the master had to support.

The chlef charge that the anti-slavery people made against Kentucky was that the State regularly bred and reared slaves for the market in the lower south. Slave dealers were mentioned in the Louisville newspapers in $1832 * 30$

In October, 1845, Rev. J. Blanchard and Rev. II. I.Rice, two Presbyterian clergymen of cincinnati, had a debate on the question "Is slaveholding in itself sinful and the relation between master and slave a sinful one.?"

Mr. Blanchard prefaced his remariss thus: "While we are debating and your are listening, anxious to know the truth on this important practical question the slave pens of a sister city, Louisville are increasing their number and enlarging their dimensions to receive slaves brought in from the upper county to send to the lower states for sale." $* 31$

The position of the General Assembly on slavery is well summed up by E.L. Warren in his history of the Presbyterian Church in Loulsville. He says, *32 "Two facts stand out conspicuously in all the history: first, the General Assembly uniformly condemned the system and, secondly, it uniformly allowed the institution a place in its communion."*33

In 1835 a report was presented to the synod of Kentucky which outlined "a plan for the moral and religious instruction" as well as for the future emancipation of the slaves under its care. This plan urged (I) The *30-Louisville Focus 1832. *31-Blanchard \& Rice Debate P 9. *32-P.18. 
emancipation of slaves at the age of 25 , (2) the recording of the emancipation deed, (3) elementary education of slaves, (4) attendance of slaves at religious services, (5) teaching of the Holy Scriptures. $* 34$

In 1849 at the state Constitutional Convention emancipation was strongly urged by the most prominent Presbyterians in the State, including Dr.R.J.Breckenridge, John C.Young, William L Breckenridge, and Rev. Stuart Robinson. *35

It is evident that opinion in Louisville was divided on the subjects of secession and slavery, because the Courier published a strong sermon by Rev. Thos. H. Hoyt in January, 1861, urging secession, and in a few days later published an address by Rev. Charles Parsons against it. Both these men were Presbyterian. *36

One of the most powerful personalities in Louisville at the time of the Civil War. was Dr. Stuart Robinson who was pastor of the Second Presbyterian Church for nineteen years beginning in 1858. In 1861 he began the publication in Loulsville of a weekly religious newspaper-The True Presbyterian, which was twice suppressed by the military because of its strong anti-union sentiment in July 1862 and November $1864 \% 37$ In 1862 Dr. Robinson was arrested by the military and after being released he went to Toronto, Canada, wher he remained until 1866, and from which place he continued to edit the paper. In 1865 the

*34-The Church and the Rebellion - Stanton P. 423. *35-The Church and the Rebellion- Stonton P. 443. *36-Daily Courier, January 5, 1861, and January 18, 1861. *37-Biographical Encyclopoedia of Kentucky P. 15. 
paper was resumed as the "Free Christian Commonwealth." After his return Dr. Robinson had a large part in the break up of the Louisville Presbytery. In 1869 he was elected moderator of the General Assembly of the Presbyterian Churches of the South. $* 38$

The break between the Presbyterian Churches North and South was the result of the political break. While in the Methodist Church the break preceded the political break and helped to bring it about.

At the General Assembly in Philadelphia in 1861, just after Ford sumter was fired on, the resolutions of Rev. Gardner Spring of. New York was presented. It read:-

"Resolved that in view of the present agitated and unhappy condition of this country, the first day of July next is set apart as a day of prayer throughout our bounds and that on this day ministers and people are called on humbly to confess and bewall their national sins and to offer our thanks to the Father of lights for his abundant and undeserved goodness toward us as a nation, to seek his guidence and blessing upon our rulers, and their counsels, as well as the assembled Congress of the United States, and to implore him in the name of Jesus Christ; the great High Priest of the Christian profession to turn away His anger from us and speedily restore to us the blessings of a safe and honorable peace. 
"Resolved that this General Assembly, in the spirit of that Christian patriotism which the Scriptures enjoin and which has always characterized this church, do hereby acknowledge and delcare our obligations to promote and perpetuate as far as in us lies, the integrity of the United States and to strengthen, uphold, and encourage the Federal Government in the exercise of all its functions under our noble Constitution in all its provisions, requirements, and principles, we profess our unabated loyalty. And to avold all misconception, the Assembly declares that by the terms of "Federal Government" as here used is not meant any particular administration or the peculiar opinions of any political party, but that central administration which being at any time appointed and inaugurated according to the terms prescribed in the Constitution of the United States, is the visible representative of our national existence."

After a heated discussion, the resolutions were adopted by a vote of 156 to sixty-six. The Southern members having but a small representation. A protest was offered by Dr. Chas. Hodge signed by fifty-eight persons, among whom were L.I. Warren, the representative of the Presbytery of Louisville, and the commissioner of the State of Kentucky. $* 40$

The protest denied the right of the General Assembly to decide to which government, Federal or state, allegiance is due. The Assembly replied, "Strictly speaking, we have not decided to what government allegiance is *40- History of Presbyterian Churches in Louisville, E.L.Warren, 
due. Our organization as a General Assembly was contemporaneous with that of the Federal Government. In the seventy-four years of our existence, Presbyterians have known but one supreme Government, and we know no other now ."

The Southern Presbyterians protested against the introduction into the discussions of the Assembly of any of the questions connected with slavery and loyalty, or the relations of the church to the civil government.

During the summer and autumn of 1861 many Presbyterians in the Southern States adopted resolutions renouncing the authority of the General Assembly, and a convention met December 4, 1861, at Augusta, George, and formed the Presbyterian Church in the Confederate States of America. $* 41$

In 1865 after the close of the war the General Assembly met at Pittsburg and passed the following regulation:

It is hereby ordered that all our Presbyteries examine every minister applying for admission from any Presbytery or other ecclesiastical body in the Southern States, whether he has in any way, directly or indirectly, of his own free will and consent, or without external constraint, been concerned at any time in aiding or countenancing the rebellion, etc., and that he be required to forsake and confess his sins in this regard before he shall be received. 
This stand aggrevated the people of the South. Having protested against the deliverances of the General Assembly from year to year, the Presbytery of Louisville adopted at Bardstown, September 2, 1865, the Declaration and Testimony. Part of it reads as follows: "Regarding the deliverances of the General Assembly as mere expressions of opinion of an advisory council to be quietly ignored if judged erroneous, but on the contrary as our standards teach in the light of solemn enactments in the name of Christ to be received with reverence when in conformity with God's work, or to be distinctly impugned and rejected when opposed thereto. The Presbytery of Louisville, after duly considering the act of the late General Assembly touching the political allegiance of ministers and members of the church, feels called upon in this solemn manner to testify against the dangerous errors in doctrine involved in that action and to repudiate the same as of no binding effect upon our ministers and churches. It appears from the reports of commissioners and from the minutes that this action was taken under constraint, directly in opposition to the Assembly's own free and uncontrolled judgment, previousIy given against making any such deliverance, that the pressure from without, from popular clamor, constrained the Assembly to reverse its decision. We feel, therefore, the less hesitancy in setting aside this deliverance on this account.

"The action of the General Assembly on this 
subject involves these essential errors.

First, the assumption of power to determine questions of political allegiance is directly contrary to the teachings of Christ and His Apostles, who uniformly enjoin obedience to caesar as a Christian duty, but obstrain from determining as between the claims of rival Caesars to the allegiance of Christians. It is notoriousiy contrary to the great distinctive doctrine of the church of Scotland, as attested by Martyrs General Assemblies and Confessions, that the power and policy. ecclesiastical is distinct in its own nature from the civil power and that the two jurisdictions confounded which God hath divided directig tendeth to the wreck of all true religion. It is directly in conflict with the corresponding declaration of our confession - Synods and councils are not to inter-medale with evil affairs, etc. It is in disregard of the testimony of the fathers who formed the Constitution of the American Presbyterian Church who,taking the principles, secured for it recognitions by the civil government in the Law of Virginia and the Federal Constitution.

Second, in answer to the protest against the resolution of the Assembly there are interpretations of Scripture which this Presbytery hold to be gravely erroneous, and also propositions concerning the relation of the civil to the ecclisiastical power which we regard as dangerous, though we deem it inexpedient to cite them in detail or make deliverance in regard to them separately from the resolution 
of the Assembly. This Presbytery utters this testimony against these errors of doctrine and principle and solemnly rejects the action of the Assembly in the premises as unconstitutional and of no binding force upon us.

"The Presbytery, believing that the Kingdom of Christ is not to be limited by civil bounds, will cordially unite with all true and conservative men in our beloved church, north or south, in defending and preserving the purity, unity, and prosperity of the Presbyterian Churches in the United States of America."

So great was the alarm that a special session of the Assembly was called in St. Louis, May 24th, 1866.*44 This Assembly adopted the following resolution:

Whereas, it is understood that the Presbytery of Louisville has openly defied the General AssembIy and refused to submit to its order in a pamphlet adopted by it, of which the following is a specimen to wit:

$$
\text { "We will not sustain or execute, or in any }
$$
manner,assist in the execution of the orders passed by the last assemblies on the subject of slavery and loyalty, and with reference to the conducting of missions in the southern states, and with regard to the ministers, members, and churches in the seceded and border stetes."

And whereas, said Presbytery has commissioned and sent to this Assembly at least one commissioner who, if the order of the last assembly had been faithfully executed by said Presbytery there is the strongest grounds for believing would have been suspended from the functions of 
the gospel ministry, therefore

Resolved: That until the Assembly shall have examined and decided on the conduct of said Presbytery, the commissioners therefrom shall not be entitled to seats in this body of the of the Louisville meetings of the Assembly.

Previously civil courts had sustained and enforced the decisions of the General Assembly as conclusive and binding.

As a result the Louisville Commissioners returned home. They were Dr. Stuart Robinson, Dr. Samuel R. Wilson, Hon. Chas.A.Wickliffe, and Mark Hardin.*45 The Assembly declared the Loulsville Presbytery dissolved and constituted those who favored the Assembly as the new Presbytery. ${ }^{* 44}$ At the meeting of the synod of Kentucky at Henderson in October, 1866, some of the churches withdrew and later joined the Southern General Assembly.

Almost immediately after the St. Louis meeting, a split occurred in the membership of the Walnut St. Church which resulted in a contest for the property. A majority of the members concurred with the Assembly while Messrs. Watson and Gault, two of the three muling elders, and llessrs. Farley and Fulton, two of the three trustees, desired to retain Rev. McElroy as pastor, as his sympathies were with the Party of the Declaration and Testimony. $* 46$

This led to efforts by each party to gain control of the property. The case was brought before the *44-Courier Jounnal 5-25-1866. *45- Daily Democrat, July 11, 12 , *46- Varren- The Presbyterian 
Synod of Kentucky, and that body by a commission called a congregational meeting. At this meeting, which had to be held on the sidewalk as the church was kept locked, additional elders, Messrs. McNaughton, Leach, and Hackney, and trustees, Nessrs. McDougal, McPherson, and Ashcraft, were elected who. were in favor of the General Assembly.

The case was brought into Chancery Court and on June 15, 1866, Judge Pirtle delivered an opinion recognizing Avery Leach and McNaughton as elders, and entered an order that the trustees Farley, Fulton, and Avery, now receivers, open the church for divine worship and congregational meetings whenever ordered to do so by the Session constituted of Avery, Hackney, McNaughton, Leach, Watson, and Gault or a majority thereof. $* 47$

This decree was reversed by the court of Appeals of Kentucky in the case of Watson vs. Avery. *48 Later the case was carried to the United States Supreme Court which upheld the decision of the Chancery court in Jones vs. Watson. $* 49$

One of the questions involved in the litigation was whether it is competent for courts of law in this country to set aside or reverse a decision of our church courts in matters that are purely ecclesiastical. - Two paragraphs from this decision answer this question:

*47-Courier - June 16, 1866. *48- Bush Reports. Vol. 2 P.332. *49- Wallace Reports. Vol.13. P.679. 
"In this class of cases we think the rule of action which should govern the civil courts, founded in a broad and sound view of the relations of church and state under our system of laws and supported by a prepondering weight of judicial authority, is, that, whenever the questions of discipline, or of faith, or ecclesiastical rule, custom or law have been decided by the highest of these church judicatories to which the matter has been carried, the legal tribunals must accept such decisions as final and as binding on them in their application to the case before them.

"The right to organize voluntary religious associations-- to create tribunals for the decision of controverted questions of faith within the association is unquestioned. All who unite themselves to such a body do so with Implied consent to this govermment and are bound to submit to it, but it would be a vain consent and would lead to the total subversion of such religious bodies, if any one aggrieved by one of their decisions could appeal to the secular courts and have them reversed. It is the essence of these religious unions and of their right to establish tribunals for the decussion of questions arising among themselves, that those decisions should be binding in all cases of ecclesiastical cognizance, subject only to such appeals as to the organism provides for."

*50-Wallace Reports. Vol.13. P.727. 
July 10, 1866, the congregation of the First Presbyterian Church approved the action of the Presbytery of Louisville in declaring its churches absolved from all obligation to obey the last General Assembly.*5I This church later joined with the Westminster Church in the building at lst and ormsby.

In June, 1866, the 2nd Presbyterian Church divided and formed the College Street Church, with Wm. Prather, Richard Knott, J.B.KInkead, and John Honnire were continued as elders. Their church, now used as a Jevish Synagogue, was completed in. 1875 at a cost of $\$ 25,000$. The Chestnut St. Church was undisturbed by the division of 1866. In 1868, McKee Mission at 4th \& Kentucly Sts. was dedicated. It became the Central Presbyterian Church in 1885 .

In 1875, following a series of services in Library Hall, it was decided to build a church that would hold 2,000 people at 4th \& Broadway. The lot was purchased for 32,000 . The church was named the Broadway Tabernacle Presbyterian Church, and later the Warren Memorial Church after Mr.L.I.Warren who paid off the indebtedness of 曹 $43,000 * 52$

At the present time there are seven churches belonging to the General Assembly of the Presbyterian Church, United States of America.(north) They are : Calvary at 24 th \& Portland, Covenant, 19th \& Jefferson, 
Fourth Avemue, Fourth Presbyterian at 119 S. Hancock, Immanuel at 3701 W. Broadway; Union at 1832 s. 2nd St., and Warren Nemorial.

There are thirteen churches under the Southern General Assembly. They are: Bardstown Rd, Berry Boulevard, Crescent Hill, First Presbyterian, Flora Helghts, Highland Presbyterian, Lee James Memorial, Portland Ave., Second Presbyterlan, South Louisville, Stuart Robinson, Third Presbyterian, and Woodland Ave. Presbyterian Churches.

Because of the various difficulties, the property of the Louisville Orphan Home Society wad divided by agreement July 26, 1869. The Northern branch retained the Preston St. property, and the Southern branch took the property at Anchorage. $* 53$

The Cumberland Presbyterian Church was organized in Kentucky as a protest against the extreme Calvinism, and against the high educational requirements for entrance inta the ministry of the regular Presbyterian Church. The Louisville was organized in 1852. A church was built at the corner of Floyd and Chestnut Sts. in 1856. This church failed and was used by the army during the Civil War. A church was built at oak and 2nd Sts. in 1887. Later this bullding was sold to the Evangelical Lutheran. The Associated Reformed Presbyterian Church now at 2 th $^{4}$ \& Broadway was organized with twenty members *53-Courier Journal, July 27, 1869. 
by the Kentucky Presbytery of the Associate Reformed Synod of the South, under Rev. Gilbert Gordon in 1854.*54

\section{Methodist.}

In 1805 and 1806, Asa Shinn was in charge of the Shelby and Salt River Circuits, with two assistants. It may be that he introduced Louisville to Methodism, prior to September 1806.*55 The first Methodist place of . worship was probably a private house next to a log building where the Court House now is, built in 1812, on land given by John and James Bate. $* 56$

Bishop Asbury, in his journal of October 22, 1812, says, "I preached in Louisville at 11 O'clock in our neat brick house 34 by $38 \mathrm{ft}$. I had a sickly serious congregation. This is a growing town and a chandsome place, but the falls or ponds make it unhealthy. $* 55$

In 1814-15 Wm. McMahon was on the Shelby Circuit Including Frankfort, Carrolton, Louisville, and the intervening towns and country societies. He preached in the Market St. Chapel and raised money to build the new church on 4 th St.

In 1815-16 William Adams was on the Jeffersan Circuit, to which Louisville had been transferred, and under his pastorate the new church had been built, the Market St. property having been sold in 1816. 
At the conference of 1818 Louisville was detathed from the Jefferson Circuit and Henry B. Baseon was appointed pastor. He served two years, and in 1820 reported one hundred whites and thirty-seven colored members. Henry Baseon began preaching at the age of 16 with but little education. He was 22 years old when he began to preach in Louisville. At the age of 27 he was made Chaplain to Congress, and at 31 President of Augusta (Ky•) College. Later became President of Transylvania University.

Until 1835, there was but the one Methodist Church in Louisville. About 1853 this 4th Street Church was abandoned and a school at 5th St. and Walnut was used. Later a church was built at this location. In December, 1888, the Walnut and Chestnut St. Churches combined and built the 4 th Ave. Church at a cost of $\$ 40,000$. Prior to the Conference of 1835, the preachers, Messrs. Wm.Holman and Deering, and the presiding elder, Crouch, with the consent of the people determined to divide the Louisville membership into three congregations as follows: The 4 th Street Church to have 101 white members and 483 colored, the Brook Street Church to have 170 white, and the 8th Street Church to have 105 white, making a total of 376 white and 483 colored.

H.H.Kavanaugh, later Bishop, became pastor of the 4th St. Church in 1835. If all his mermbership had attended he would have had nearly five colored hearers to one white. "The whites occupied the body of the church and the others the long,wide, and well ventilated gallaries. 
Many negroes were good singers and joined heartily in singing familiar hymns and with the preacher repeated every two lines, as was the custom with the opening hymns. $* 57$ When there were two pastors at the 4 th St. Church one gave his attention to services conducted in a fire engine hall on 8th street and one gave special attention to services to the colored people Sunday afternoons and week nights at the church.

Rev. Holman with 170 members built a two story brick church on the west side of Brook St. between Market and Jefferson which was dedicated in 1839. The church was destroyed by fire in 1852 and rebuilt. In 1865 it was sold to the Catholics for par $_{20}, 000$ and is still in use. The congregation then moved into the Broadway Church valued at $\aleph_{16} 75,000$.

Drummond Welburn was sent to "Upper Station" in September, 1843, to form a congregation and build a chapel. In 1845 a two story brick church at the corner of Shelby \& Main Sts. was dedlcated. This is now the Marcus Iindsey Memorial Church which has in connection with it the wesley Community House. $* 58$

*57-Johnston-Memorial History. P.211.

*58-"Marcus Iindsey was one of the most prominent Methodists of early Kentucky. In 1816 he was instrumental in the conversion of a Virginia raised negro at Narietta, 0,John stewart by name. Well stocked with old time hymns, with a melodious voice, gifted in prayer, and with a religious knowledge acquired from the white people. He went to the Wyandotte Indians at Upper Sandusky, Ohio. Found a competent negro interpreter at Sandusky and he lead many of the Indians into Christianity, including several chiefs.-- Johnston's Memorial History. Vol.2 
In 1840 a German Methodist Church was started on Clay Street near Jefferson to meet the needs of the newly arrived German immigrants. In 1880 they built a larger church on Market st. west of Clay at a cost of $\$$ 25,000. This is now known as the Market Street Church. It has always been a member of the Nethodist Church. (North).

In 1842 a Seamen's Bethel was started on Front Street and continued to serve the men on the river boats for forty years.

The Methodist Ghurch and Slavery.

The Methodist Episcopal Church in America was organized at Baltimore in 1784, and at that time mules of John Wesley forbidding slavery within the church were adopted. This Conference also drew up rules looking toward the wiping out of the slave system. Later in 1800 the rules were changed so that only church officials were required to emancipate their slaves, and preachers who became slave holders were required to withdraw from the ministry or else emancipate their slaves in states where emancipation was permitted by law. $* 59$

When the anti-slavery agitation fathered by Garrison began in the early thirties, it met a considerable response in the Methodist Church, and in the north a number of Nethodist anti-slavery societies were formed. $* 60$ The Methodists of the south recognized the evils of slavery and 
Wished to abate them, but with due regard to the interests of the negro himself and the safety of the public. About 1835 a committee of the Kentucky Conference submitted the following: "Although citizens of Kentucky, we are not advocates of slavery. We believe it to be morally wrong, and relatively mischieyous in all its tendencies. We consider it an evil even in its most tolerable aspects. We deeply regret and anxiously deplore its existence in this or any country, and in relation to our own particularly, we pledge our exertions and influence in an appeal to all just and lawful means and methods for its removal, whenever such exertions and influence can be brought to bear without infringing the rights of others constitutionally secured in the construction of the Federal Government." This report bears the names of H.B.Baseom, J. Stamper, J. Iittleton, J.S.Tomlinson, H.H. Kavanaugh, R. Corwine, J. Tevis, and J. Beatly, and this attitude was maintained by the whole church until 1840.*6I

But the abolition movement gained in strength and it was to this "radicalism" that the southern people objected. When the general conference met in 1844, over one hundred and fifty petitions and memorials were presented against slavery and Bishop Andrew of Georgia was the one around whom the storm broke.

The Bishop had a slave girl left him by an old lady of Augusta, Georgia, on condition that he should 
liberate her and send her to Siberia, with her consent. But on reaching the required age the girl refused to go to Liberia and remained legally the property of the Bishop. He had also inherited from his first wife a slave boy which, by law, he could not free and on his second marriage, he married a lady who had inherited slaves from her former husband's estate.*62

No bill of charges was brought against Bishop. Andrew and no trial was had. The conference merely on the "grounds of expediency" passed a resolution that it is the sense of this General Conference that he desist from the exercise of this office so Iong as this impediment remains.*63 Four days later fifty-one delegates from the Southern Conferences presented the following:

"rhe delegates of the Conferences of the slaveholding states take leave to declare to the General conference of the Methodist EpIscopal Dhurch that the continued agitation on the subject of slavery and abolition in a portion of the Church; the frequent action on that subject in the General Conference; and especially the extra-judicial proceedings against Bishop Andrew, which resulted, on Saturday last, in the virtual suspension of him from his office as Superintendent, must produce a state of things in the South Which renders the continuance of the jurisdiction of this General Conference over these Conferences inconsistent with the success of the ministry in the slaveholding states." At the same session, on motion of J.B.McFerrin, *62-Sweet-The liethodist Episcopal Church and the Civil War$* 63 "$ 
it was:

$$
\text { "Resolved, that the committee appointed to }
$$

take into consideration the communication of the delegates from the Southern Conferences be instructed, provided they cannot in their judgment devise a plan for an amicable adjustment of the difficulties now existing in the church, on the subject of slavery, to devise, if possible, a constitutional plan for a mutual and friendly division of the church."

This was referred to a special Committee of nine. This committee consisted of three men from the South, Robert Paine, Thomas Crowder, and William Winans, and six from the North. On June the 8th, the Committee brought in the following:

Whereas, a declaration has been presented to this General Conference with the signatures of fifty-one delegates of the body from thipteen Annual conferences in the slaveholding states, representing that for various reasons enumerated, the objects and purposes of the christian ministry and church organization cannot be súccessfully accomplished by them under the jurisdiction of this General Conference as now constituted; and

Whereas, in the event of a spearation, a contingency to which the declaration asks attention as not improbable, we esteem it the duty of this General Conference to meet the emergency with Christian kindness and the strictest equity; therefore,

Resolved, by the delegates of the several 
Annual conferences in General Conference assembled,

"1. That, should the Annual Conferences in the slaveholding states find it necessary to unite in a distinct ecclesiastical connection, the following rule shall be observed with regard to the northern boundary of such connectipn, all the societies, stations, and Conferences adhering to the Church in the South, by a vote of a majorit.y of the members of said societies, stations, and Conferences, shall remain under the unmolested pastoral care of the Southern Church, and the ministers of the Methodist Episcopal Church shall in no wise attempt to organize churches or societies within the limits of the Church south, nor shall they attempt to exercise any pastoral oversight therein, it being understood that the ministry of the South reciprocally observe the same mie in relation to stations, societies, and Conferences adhering, by vote of a majority, to the Methodist Episcopal Church, provided also, that this rule shall apply only to societies, stations, and Conferences bordering on the line of division, and not to interior charges which shall in all cases be left to the care of that Church within whose territory they are situated."

There were eleven other sections of this resolution, providing for a division of the property of the church, etc.

On liay 1, 1845, the Southern churches held a convention in Louisville at the 4 th St. Church. (It was probably held in Louisvilie because the city, being one of the largest in the South, was easily accessible by boat 
and by stage coach and because Dr. Bascom, one of the leaders, was located in Kentucky at Transylvania University -(Mr.W.E.Arnold - Central Methodist.)

Just a few days preceding the meeting, the morning Courier quoted a letter from Henry clay, indicating that the action of the Church carried forbodings of political trouble. He said,"I will not say that such a separation would necessarily produce a dissolution of the political union of these states, but the extreme example would be fought with imminent danger." At the same time the Courier carried lon' excerpts from Dr. Baseom in defense of slavery.

The convention lasted seventeen days and was presided over by Bishops Andrew and Soule. After much discussion, in which it was taken for granted that a separate organization would be formed, two resolutions were adopted by a vote of ninety-four to three, one announcing a separation under the provisional plan adopted in New York in 1844, and the other that they would consider any plan of union of the Northern and Southern Churches. $* 64$

At the time of this convention, Louisville was chosen the location for the Southern Methodist Book Concern because it was felt that she possessed greater advantages than the other cities. An attempt was made to make it the Parent Mission Station, but this failed. 
In a few months the' conferences all over the South voted to adhere to the Methodist Church South. It was not long, however, before the Northern Church claimed that the South had violated their agreement in the conference of 1844. Immediately, each church began to make great efforts to retain the border, and there was more or less constant conflict between them along the border even through the Givil War. ${ }^{65}$ As the political situation grew more tense the churches grew farther apart. The Nashville and Louisville Christian Advocate, the chief journal of the south Church, criticized, in his paper of April 6,1854, the editor of the Christian Advocate and Journal (Cincinnati) for his editorials on the subject of slavery, "We most sincerely wish that he and all the religious editors in this land would attend to their appropriate work and leave great national questions and state politics to the people as citizens. $* 66$

The Methodist Church, South, in Kentucky contained large numbers of strong union men, in fact, loyal. sentiment was stronger in the Church South in Kentucky than in any other place. "In 1862 thirty-six preachers from the Louisville Conference were determined to adhere to the Union and many of them intimated that if the states separated they would return to the M.E. Church (North). There were four rethodist Chaplains from the church south with the Union Army. They were M.N.Lesley, J.H.Bristow,

*65- Sweet-The M.E.Church and the Civil War. P.34. *66- Sweet-The M.E.Church and the Civil War. P.45. 
H.T.Burge, and Robert G.Gardner. $* 67$

From the time of the Convention of 1845 there

were no fraternal relations between the churches North and South until 1874, when the General Conference South met in Louisville. Delegates were sent from the North and ever since then fraternal delegates have been exchanged. In January, 1920, the meeting of a joint commission on unification was held at the 4 th Ave. Church in Louisville. A plan was agreed upon, but is still pending. The North took no action but suggested another plan (Mr.W.E.ArnoldCentral liethodist.)

Now it is well to review the development of the various local churches since the convention of 1845 . In 1845 an African $\mathbb{M} . E . C h u r c h$ was organized and a church built on 9 th St. near Walnut. Five years later Quinn ChapeI on Grayson St. near 9th was erected. In 1846 a Mission was started at 17 th \& Jefferson where in 1855 a churdh was built.

In 1848 a mission was started at 14 th \& Jefferson Sts. in an old school. Later the 12th St. Church was organized and built on lst street between Market and Jefferson. This church was later sold to the Zion African M.E.Congregation.

In 1849 E.W.Sehon was made pastor of Trinity M.E. Church at Third and Gutherie Streets, and a church was built. This is the church that became Episcopalian and *67-Sweet-The M.E.Church and the Civil War. P.57. 
from Which Calvary Episcopal Church started. Warch 19, 1865 Trinity Jiethodist Church was organized under the $\mathrm{H}$. E. Church North by Rev.J.H.Bristow, former chaplain in the Union Army. About a month later they bought the old Universalist Church on Narket and Eighth St. $* 68$ The Courier Journal of March 24, 1866, because it was Southern in sympathy, predicted failure for this church which sympathized with the North. In 1872 the property at Third and Gutherie was taken over again and is still in use.

In 1860 a brick church for the people of Shippingport was organized.

In $1863 \mathrm{~J} \cdot \mathrm{H} \cdot$ Iinr became pastor of the $8 \mathrm{th}$ St. Church. He built a new church on chestnut St, at a cost of 40,000 during the war which was quite an accomplishment. $* 69$

In 1890 the Clifton Church vas started. The Wilson Memorial Church in Parkland was organized in 1892, and the Highland Church in 1896. The Third German Church was built at Breckenridge and Clay streets in 1890.

In 1906 the Temple was purchased at 6th \& Broadway from the Adath Isreal congregation.

As will be seen from the chart in the appendix the strongest period of development of the Nethodist Church has been from 1890 to 1920. This is due in part to the fact that the Board of Church Extension of the Hethodist Church South has been located in Louisville since 
1882, and the Louisville Methodist Alliance, which aids new churches in the city, was organized about that time. There are now six Methodist Churches North, twenty-one white of the Church South, and nineteen colored, South.

\section{Christian.}

Alexander Campbell and his father, Thomas Campbell, founded the Christian Church or Disciples of Christ in 1810 at washington, $\mathrm{Pa}$., having broken with the Baptist Church. In 1824 Alexander Campbell visited Louisville. He spoke so eloquently that George D. Prentice eulogized him in the Louisville Journal. *70 M.J.Torbitt wrote in 1833, "In the winter of $1821 \mathrm{P} . \mathrm{S} . \mathrm{Fall}$, having been then about tro years in the" ministry of the Baptist Church,was invited to visit Louisville for the purpose of preaching. A few Baptists who had organized into a church met on this occasion to attend to church business and worship on Saturday as their. custom. On Sunday, they occupled the court House which was filled to overflowing. In $1823 \mathrm{hr}$. Fall came to Louisville and opened a school. About this time he received a copy of Alexander Campbell's famous sermon "The Law". Several numbers of the paper, The Christian Baptist, fell into his hands. During the later part of 1824 and in 1825 the congregation was accustomed to break the loaf every Lord's Day and to attend regularly to the contribution for 
the poor. These duties were felt incumbent upon it after the example of the early Christians.

A little later Rev. Fall preached a sermon at the meeting of the Long Run Baptist Association. He proceeded to show that the Word of God is the only and the sufficient and perfect mle of faith and practice. His teachings were assailed and the Association became divided in its opinions, although they worshipped together for several years.

In 1829 at the usual monthly Saturday meeting for business was held. A dissension arose over the two doctrines and Cornelius Van Buskirk seized the church book and one of his party pocketed the key to the church and locked out the majority who represented the New Testament (or (Campbell's Party). A law suit resulted and the old Constitution Farty (Baptists) had to yield to the New Testament party. In the meantime the occupation of the church was equally divided between the two parties. All this time the New Testament Party regarded themselves as the Baptist Church, and they bore the name, "The First Baptist Church of Jesus Christ of Louisville, $\mathrm{Ky} \cdot$ ", and not until 1833 did they assume the name Disciples of Christ.

In Warch 1835 they sold their entire interest in the house at the corner of 5 th \& Green Sts.

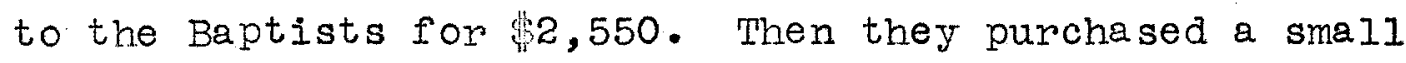
house from the Primitive Methodists on 2nd St. between Market and Jefferson.

During 1836 a lot was purchased on 5th St. between walnut and Chestnut, and the church built in 1837 . 
In 1846 they bought a lot and built at Fourth \& Walnut where the Starks Bldg. now is. In 1860 this church was found to be too small and it was torn down. The new cornerstone was laid in 1860, and the church finished in 1870 at a cost of 66,000 .

During the Civil war the regular meetings were held and although political animosity was strong, harmony largely was preserved. Henry T. Anderson was pastor for eleven years at that time and was very influential. Rev.E.I.Powell came in 1887.*7I November 12, 1911, the new church at 4 th St. and Breckenridge St. was dedicated. Since Dr. Powell came in 1887 there have been thirteen white Christian Churches and three colored built up in the city.

\section{Unitarian.}

The Unitarian Church was started in the United States in Boston after the Revolutionary War. In May 1825, the American Unitarian Association was organized. The church in Louisville was organized July 3, 1830, after the visits of several Unitarian preachers to the city. The church was dedicated May 27, 1832 and on that occasion Dr. Francis Parkman and Dr. James Walker, afterwards President of Harvard, took part in the services. The building is described in the Louisville Directory of 1832 *71-Johnst on Memorial History - Vol.2.P.24l. 
as follows:

"The First Unitarian Church furnishes the neatest and most chaste specimen of architecture in the city. It stands at the southeastern intersection of 5 th \& Walnut st. fronting on the latter. Its dimensions are $75 \mathrm{ft}$. long and $46 \mathrm{ft}$. wide, and $26 \mathrm{ft}$. high above a basement story of $10 \mathrm{ft}$. from the ground. The vestibuite of the building is 15 feet high. The front of this handsome specimen of the art of building presents the style of the Grefian Dome with four columns supporting a pediment frieze and entablature, from the center of these (rising 15 feet above the apex of the cornice) springs a square tower, intended to support a belfrey and spire. This building is receiving a coat of marbled stucco which promises to place it in taste and beauty beyond any building in the city. The interior of seventy-four pews will, with the gallery, accommodate 650 persons. We owe this neat and beautiful temple, dedicated to the worship of the Iiving God, to the liberal spirit of a few gentlemen: who have supported the burden and the heat of the day.'

Rev. George Chapman of Boston was the first pastor. He was employed at a salary of $\$ 600$ a year. $" 73$ He remained but one year and was followed by Rev. James Freeman Clarke who was employed at $\$ 800$ a year provided that much is subscribed and paid in. Mr. Clarke was a clear vigorous thinker. He was a public spirited citizen and deeply interested in the welfare of the community. He devoted much of his time to the Public Schools and in 1839. was 
chosen "agent" - that is secretary and superintendent, by the city counc11. In 1836 he became editor of the Miessenger, a paper devoted to liberal Christianity which was transferred here from Cincinnat1. He resigned in 1840 leaving a very strong congregation.

He was succeeded by Rev. John H. Heywood, a graduate of Harvard College and Divinity School. He was pastor for forty years and was very successful. In 1859 a "night school" - perhaps a pioneer one was established in the hall of one of the city's engine houses. 'the school was conducted by the young men of the congregation. Many successful men of later years got their start here. $\$ 74$. In 1865 an old ladies home was established by the church which in 1882 was transferred to the well endowed Cook benevolent Institution. During the Civil War the ladies ald much hospital work and work for the United States vanitary Commission.

Soon after the congregation of the Unitarian Church, the Universalist Church was started. It prospered for a while but died out about the time of the Civil war. Those most deeply interested united with the Unitarians after the Warr, and the money derived from the sale of their building was given toward the erection of the lhurch of the Messiah, at 4th \& York, which was built in 1870. It was destroyed by fire shortly after its completion but soon rebullt.

During the early nineties the Unitarian

*74 - Johnston Memorial History Vol. 2, P. 253. 
Church conducted a Mission S unday School on East Broadway but it was not continued'long. In spite of this church's growth and activity, it is still the only Unitarian Church in Kentucky.

\section{English Lutheran.}

The Lutheran church has always been an orthodox evangelical church. In its beginning it stood for the teachings of an unchangeable $\mathrm{Blble}$, and there has never been any disposition to change its doctrinal position. Its creed is expressed in the Augsburg Confession. $* 75$.

About 1805 a colony of ten members of the Lutheran falth came to Boone County. They immediately established regular worship and continued it for eight years without a pastor. One of their own number read a sermon each sunday. In 1806 they organized a congregation calling it the "Hopeful Church," the name it holds today. Kev. William Carpenter, their former pastor, came in 1813 from Virginia and was probably the first Lutheran minister in Kentucky. After this the next Lutheran settlement was formed at Jeffersontown. In 1819 they organized a church one mile from Jeffersont own.

On December 25, 1842 Rev. W.R. McChesney organized a church with twenty-five members in Louisville. They worshipped on Second between Market and Jefferson Dtreets. The city directory of the year previous to this reports an Evangelical Lutheran congregation in the same place, under a Rev. August Kreel. This effort failed, however, as did those of Rev. John Krack who moved to Louisville from Jeffersontown in 
1847 and worked for the establishment of a church. In 1856 another church was organized but disbanded.

During the period of the Civil War there was no Iutheran church in the city. It is well known that the German people, who later comprised this church, were opposed to slavery and in sympathy with the North. Only the churches within the confederate Ines broke off to form the General Synod, South, at Concord, N.C. on May 20, 1863. \#76.

In 1870 the Olive Branch Synod took favorable action looking toward the organization of an English Lutheran Church pledging five-hundred dollars to the enterprise. Iittle seems to have resulted from this. The First English Lutheran Church was the outgrowth of an undertaking in 1871 by the Home ission Board of the General Synod. In the early spring of 1872 Rev. J.M. Ruthrauff of Wittenberg of Wittenberg College came to the city with a view to establishing a Lutheran mission. In May regular services were begun in Bowles Hall at the corner of Preston and Jefferson. In this hall on June lst the First English Iutheran Church was organized. services were held there until December, then changed to the Presbyterien Chapel on Caldwell Street near Preston. Soon a lot on Broadway between Preston and Jackson was purchased and on March 21, 1875

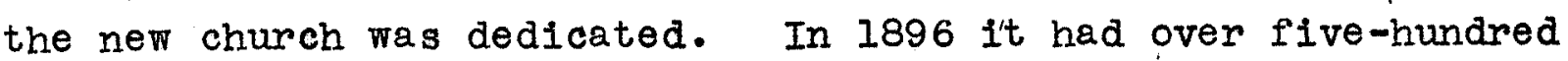
members.

The Second English Iutheran Church was the outgrowth of a mission of the First Church. On January 30, 1876 a sunday School was started in Falls City Hall on Market street near $12 t h$. Later in 1877 a church on Walnut between 18th and 19th was 
purchased and the organization of the Church took place. Rev. H.K. Fenner was called as pastor and still serves in this capac1ty. He built a church on Jefferson Street between 21 st and 22nd. The Third English Lutheran Church also sprang from a $S$ unday School. On February 18, 1880 the school was organized by Rev. Dr. J.S. Detweiler in what was known as the old Gymnasium on Ma1den Lane and Adam Street. On May 17, 1886 a church was

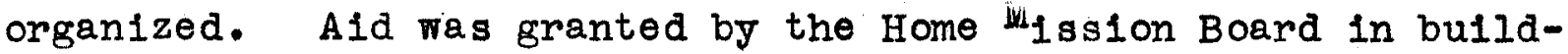
Ing the church at Story and Frankfort Avenue which was finished, in 1887.

St. Paul's English Iútheran Church was organized January 24, 1890 with thirty-nine members from the First Church. The congregation worshipped for some time at Hancock and $\mathrm{K}_{\text {oselane }}$ (now the Presbyterian Colored Mission.) It later built at the corner of Brook and Breckinridge Streets, but later bought the church at 2nd and oak which was built originally by the Cumberland Presbyterian Church.

Grace Church on 26th Street near Bank was organized October 11, 1891. On the same day it dedicated its house of worship, it being an off shoot from the second Church. Trintty Church was organized in 1892 at Cardon1's Hall, at Baxter and Broadway from a Sunday School. Later a church costing fourteen-thousand dollars was built at the corner of Highland and Rubel Avenues. It was finished in 1895.

These six churches were in 1896 to be the oldest and most thoroughly Anglicized general body in the Iutheran Church in America. Then they had one-thousand, four-hundred and seventeen members, two-thousand, one-hundred and twelve sunday shool 
members, and church property valued at seventy-six-thousand dollars. There are now about twenty-five hundred communicants in Louisville. The churches are members of the central body known as the United Iutheran Church in North America.

\section{German Evangelical.}

The Evangelical Synod of North America endeavors to unite the Iutheran and the Reformed branches of the evangelical Protestant church. It accepts the Augsburg Confession, Iuther's Small Catechism and the Heidleberg Catechism so far as they agree but in points of difference it makes, use of the liberty of consclence which exists in the Evangelical Church. It corresponds to the State Church of Germany established by Frederick the Great.

St. Paul's is the oldest German Frotestint Ghurch in the city and is the mother church of all others in the city belonging to the Synod. It was organized about 1830 and the congregation worshipped at 4 th and Green Streets. In 1842 a church was built at Preston and Green and in 1861 the church on Broadway was erected.

St. John's was organized in 1842 and a building was rented on Fifth Street between Green and Walnut Streets. In 1848 a church was bullt on Hancock Street between Market and Jefferson. In 1869 the present large church was built. It is the strongest church in the Louisville Synod.

St. Peter's was organized in 1849 and a church built on Ilth Street at Grayson. In 1895 a new church on Jefferson between 12th and 13th Streets was built. Other churches are $\nu_{t}$. Luke's on Jefferson Street near 19th, Christ Church at Barret Avenue and Breckinridge, St. Matthew's on St. Catherine and 
and Bethlehem Church at 6th and Hill Streets.

German Evangelical Lutheran.

The First German Evangelical Lutheran Church, now 10cated on Broadway near Underhill Street, was organized in 1878. It is a member of the Missouri Synod. In 1880 the congregation numbered thirty-five families. In connection with his pastoral duties the pastor conducts a parochial week day school.

The Second Evangelical Lutheran Church was organized in 1889 with thirty-five families. A chapel at 22nd \& Madison Streets was bought. It also has a parochial day school. Jew1sh.

It was not unt1l after 1840 that there was anything like a distinct Jewish element in Louisville. The city directories published in the ' 30 's show only a few in the list of residents - very few of whom had any social or business prominence. There was no Jewish congregation on record prior to 1842, when the regulation prescribed ten as the lowest number entitled to associate themselves into a religious society. The well known tendency of the Jews to organize for worship suggests that they were not here in sufficient numbers to warrant an organization prior to 1840 .

In 1842 the first Jewish place of zorship of which there is any record was on Main Street between brook and First Streets.

Another of the oldest congregations had its synagogue on the South side of Market Street near First. A third was on Green Street between First and $\mathrm{S}_{e}$ cond which was in existence until 1895. 
Jewish worship cannot be said to have taken a firm foothold in Louisville until the organization of the Adath Israel Congregation, which was incorporated by the Legislature in 1843.

That the immigration of the Jewish element was comparatively recent is shown by the fact that not one of the names of the incorporators of 1843 is listed in the directory of 1838-9. so between 1840 and 1843 was the period when the Jews became established. The first permanent house of worship of the Adath Israel Congregation was on the East side of Fourth Street between the Poljtechnic and the Courier Journal Bullding. It was a wooden structure. It was destroyed by fire in 1865. In 1967-8 the temple at the corner of 6 th and broadway, now the Methodist lemple, was erected. It is an oriental structure of Byzantine architecture.

The most famous pastor of this congregation was Rabbi J.I. Moses who was born in Prussian Poland. He came to Louisville in 1881. He belonged to the advanced wing of the Keformed Jewish Church of America. He opposed the "chosen people" 1dea: He was a strong speaker and leader on social questions. There are at present seven congregations in the city. Religious Education.

Religious education has always been a strong aspect of the religious life of the city. In 1822 the Loulsville Bible Society was started. Its report for 1832 shows that during the year previous it had supplied thirteen counties in the state with Bibles. There were five Sunday Schools in Louisvilie that year. The last report of the Bible Soclety published in 1911 
says "the last general canvess of the city was made in 2004-5. It showed thirteen-thousand homes had been visited; two-thousand, four-hundred and forty were found without the Blble, of which twenty-one thousand were supplied by donation and one-thousand, four-hundred and forty by sales. In these homes sixteen-thousand, nine-hundred and eighty-six adults were found not attending any religious services and seven-thousand, one-hundred and eighty-one children not attending a Sabbath school.

\section{Catholic.}

In 1831 under Mother Catherine Spalding and two other sisters of Nazareth, the Presentation Academy was started in a building next to where the cathedral now stands. Later a building next to the Fifth Avenue Hotel was used for fifty years. The Academy was then moved to its present bullding at Fourth and Breckinridge Streets. It has over three-hundred pupils and sixteen sisters of Charity of Nazareth as teachers.

In 1832 the Jesults started a free school for boys which continued for a short while.

In 1842 the Mount Saint Benedict or Ledar Grove Academy on $\mathrm{N}$. 35th Street was established. It now has over one-hundred pupils.

The order of Xaverian Brothers was started in belgium in 1839. Representatives of this order were brought to the city by Bishop Spalding and opened school at St. Patrick's Uhurch. In 1864 they opened a high school in the large building adjoining St. Joseph's Infirmary, now St. Helena's House. In 1892 they purchased their present quarters, St. Xavier's vollege, which was formerly the Newcomb residence. It was rebuilt in its present form in 1901. It has an enrollment of about six-hundred 
students.

The first Holy Rosary Academy which is conducted by the Dominican Sisters was started in 1866 in a double two story brick house on Fifth Street. In 1869 they rebuilt at 8 th and rentucky Streets. In 1895 they moved to $412 \mathrm{~W}$. Ormsby. 'they are now located on Park Avenue between Third and F'ourth.

The National Catholic Directory shows for 1920 ninethousand and sixty-two pupils in parochial schools and two-hundred and two teachers.

\section{Presbyterian.}

Two institutions destroyed by the war were the rresbyterian Female School on Sixth Street, which was conducted by Professors Williams and Barton, and the Presbyterian University which was established in 1859 of which Dr. Stuart Robinson mas President. The foundations were laid for the building in 1861 at the corner of Second and College Streets.

The Presbyterian Theological Seminary was started by the Southern Presbyterian Assembly in 1892 and was known as "The School of the Prophets." The first year it had an attendance of thirty-one, the second year fifty-two and the third year sixty.

In 1901 it was consolidated with the Danville Seminary founded in Danville in 1853. It is now under the Synod of Kentucky and the Synod of Missouri and under the general oversight of both the Northern and Southern branches of the church, each being represented by six members on the Board of Directors. The present building cost two-hundred and twenty-thousand dollars. The invested funds of the Seminary amount to more than fivehundred thousand dollars of which the scholarship fund is fortythousand dollars. It hàs a library of over twenty-thousand 
volumes. Dr. John M. Vander Meulen became President in 1920. 'Ihe Seminary has about sixty students.

\section{Episcopal.}

Trinity Hall, located on the outskirts of the city, just Worth of Cave Hill Cemetery, was a school started as the diocesan

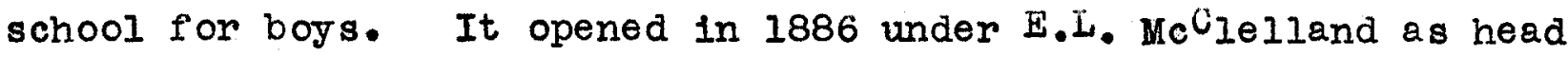
master. It ran for five years and then closed for two because of the ill health of the head master. In 1893 Rev. W.T. EImer, M.A. took charge but the school continued only a few years. The buildings are now occupied by Beechhurst Sanatorium.

\section{Baptist.}

The Southern Baptist Theological Deminary was organized as a result of an educational convention held in conjunction with the Southern Baptist Convention in 1857 when plans were made for its establishment in Greenville, S.C. It was started in 1858 under the leadership of James P. Boyce and In October 1859 it opened its doors with four professors, James P. Boyce, John A. Broaddus, b. Wanly, Jr. and William Williams. Twenty-six students entered the first year, thirty-six the second year from all parts of the south. \#77. Before the end of the second session came the $C_{1}$ ivil War. At the close of the third session classes were suspended. The salaries of the faculty continued to be paid, but in Confederate money .

Dr. Boyce was for some months chaplain to a Confederate Regiment. He was an ardent pro-slavery man. *78. When the war closed the professors assembled in Greenville, in the summer of 1865. 
Much of the two-hundred thousand dollars endowment was uncollectable because of the financial condition of the South, but the scho continued until 1877 when in its last session it had sixty-five students.

The State feeling was so strong that $D_{r}$. Boyce's efforts to raise money had to be under the arrangment that the State that had the $S_{e}$ minary must raise as much as was raised elsewhere.

South Carolina could not do this. 'there was little in the way of equipment to be moved to Loulsville - only a few thousand volumes and three professors, Broaddus, Toy and witsitt.

In 1886 a contribution from New York friends made possible the erection of liew York Hall. The library was the gift of Mrs. J. Lawrence Smith. Later Worton Hall costing sixtythousand dollars was built.

In 1899 Dr. E. Y. Mullins became President and still serves in that capacity.

At the fiftieth anniversary in 1909 a campaign for an endowment of six-hundred thousand dollars was started.

At present this seminary is the largest in the United States.

The Woman's Missionary Union Training School at Preston and Broadway was opened May 22, 1918 under Mrs. hilliure as Superintendent. It was the outgrowth of fifteen years of work and interest in the missionary training field among the women of Louisville. It is closely affiliated with the Seminary.

Efforts in united action have been through the Churchmen' Federation which was organized in 1910. Mr. C.C. Stoll was the originator. Until 1916 this Federation worked through committee 
After $1916 \mathrm{Mr}$. C. J. Meddis was employed as Executive Secretary and in 1917 Rev. Dr. W. S. Lockhart succeeded him.

The Churchmen's Federation now combined with the Church Women's Federation, organized in 1920, are carrying on a fight against vice and gambling. In 1915 they made a Vice jurvey. At the State Legislature in 1920 they made a strong fight against the par1-mutuel gambling at race horse and against prize fighting. They also united the Protestant forces in a large religious revival in 1920, led by "Gypsy Smith," Farly in 1920, in connection with the Inter-Church World Movement they undertook three surveys - one in the Industrial field, one of Housing and one religious census. The results of these surveys were never printed because of the abandonment of the Inter-lihurch Movement. The Ministerial Association, which is made up of the Protestant ministers, with the exception of the Unitarian Minister, has been in existence for over forty years. 


\section{Bibliography.}

Allen - Histiory of Kentucky - 1872 - Bradley \& Gilbert, Loulsvilie, Ky.

Bagcom - Methodism and Slavery - 1845 - Hodges -

Krankfort, Ky.

Biographical Encyclopedia of Kentucky - 1876 - J.M. Armstrong \& Co., Cincinnati, 0 .

Blanchard \& RIce - A Debate on Slavery - 1846 - W.H. Moore \& Co., Cincinnat 1,0 .

Broadus - Memolrs of John P. Boyce - 1893 - Armstrong,

Bush, Kentucky Reports. New York.

Christy - Pulpit Politics - 1862 - Faran, Cincinnati.

Craik - Historical Sketches of Christ Church - 1862 Mort on Co., Loulsville.

Collins - History of Kentucky - 1882 - Collins, covington, Ky.

Durrett - Centinary of Louisvilie - 1893 - John P. Morton Co., Louisville.

Davidson - History of the Presbyterian Church in Kentucly - 1847 Robert Carter, New York.

History of the Ohio Falls Cities - I882 - L.G.Williams \& Co, Cleveland, 0 .

In Memoriam - James Craik - 1882 - Morton Co.,

Louisvilie.

Jacobs - The Lutherans - 1893 - The Christian Iiterature Co., New York.

Johnston - Memorial History of Louisville - 1896 - American Blographical Pub. Co., Chicago.

McDougle - Slavery in Kentucky - 1918 - Clark University, Worcester, Mass.

McMurtrie - Early Sketches of Louisville - 1819 - Penn Iouisville.

Smith - History of Kentucky - 1901 - Prentice Press Louisvilie.

Spaulding - Sketches of Early Catholic Missionaries in Kentucky 1827 - Webb, Louisvilie.

Sweet - The Methodist Episcopal Church and the Civil War - 1912 Methodist Book Concern, Louisvilio

Stanton - The Church and the Rebellion - 1864 - Derby \& Miller, New York.

Spencer - History of Beptists in Kentucky - 1886 -

Spencer, Louisvilie.

Warren - The Presbyterian Church in Louisville - 1896 Chicago.

Wallace - United States Supreme Court Reports.

- Webb - Centinary of Catholicity in Kentucky - 1884 - Rogers, Louisvilie.

Dasher - Souvenier Program of General Assembly of Presbyterian Church, 1912. 
Minutes of the Long Run Baptist Association.

After Thirty Years (History of Trinity Methodist Church, Churchmen's Federation Report - 1920 - Louisville. Weaver - The Baptist Cause in Louisville - 1907 -

The Iutheran Almanac, 1916. (pamphlet)

The official Catholic Directory, 1921. The Western Recorder - 1860-1865, Loulsville. The Central Methodist, Volume 55, \#9,10,13, and 17, The Louisville City Directories. Louisville, 1921 .

Louisville Da1ly Democrat, June, 1866. Louisville vourier Journal, July and August, 1869. Louisville Daily Courler - 1854 . Louisville Focus - 1832. 


\section{$\begin{array}{lllll}1800 & 1810 & 1820 & 1832 & 1840\end{array}$}

\begin{tabular}{|c|c|c|c|c|c|c|c|}
\hline Presbyterian & & & $I$ & 4 & 3 & & \\
\hline Cumberland pres. & & & & & & & \\
\hline Colored & & & & & & & \\
\hline Associate & & & & & & & \\
\hline Episcopal & $I$. & 0 & & $T$ & $\mathbf{Z}$ & & m \\
\hline Colored & & & & & & & to \\
\hline Unitarian & & & & I & $I$ & & + \\
\hline Methodist & & & $I$ & 2 & $\Phi$ & & 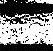 \\
\hline South & & & & & & & \\
\hline German North & & & & & & & \\
\hline Colored & & & & & & & \\
\hline Catholic & & & $I$ & & Z. & 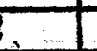 & \\
\hline Colored & & & & & & & \\
\hline Evangelical & & & & & $I$ & & \\
\hline Reform & & & & & & & \\
\hline Bapt1st & & & $I$ & $I$ & $\overline{2}$ & & \\
\hline Colored & & & & $I$ & I & & \\
\hline Christian & & & & & I & [ & \\
\hline Christian & & & & & & & \\
\hline Univergalist & & & & & & & \\
\hline Church of christ & & & & & & & \\
\hline (colored) & & & & & & & \\
\hline Lutheran & & & & & & & \\
\hline New Jerusalem & & & & & & & \\
\hline Jow1sh & & & & & & & \\
\hline CongregationaI & & & & & & & \\
\hline Seventh Day Adventist White & & & & E- & & & \\
\hline $1 "$ " Colored & & & & & & & \\
\hline Christian science & & & & & & & \\
\hline PentecostaI & & & & & & & \\
\hline Colored & & & & - & & & \\
\hline TOTAL & 1 & 0 & 4 & 1.0 & 17 & & \\
\hline Population of city & 359 & $1375^{*}$ & 4012 & 10336 & 1210 & & \\
\hline $\begin{array}{l}\text { Average number of people per } \\
\text { church }\end{array}$ & 359 & 1375 & 1003 & 1033 & 1247 & & \\
\hline
\end{tabular}

The above figures show the number of churches in Loulsville every ten years since 1800, also the average number of people per church according to population. 
